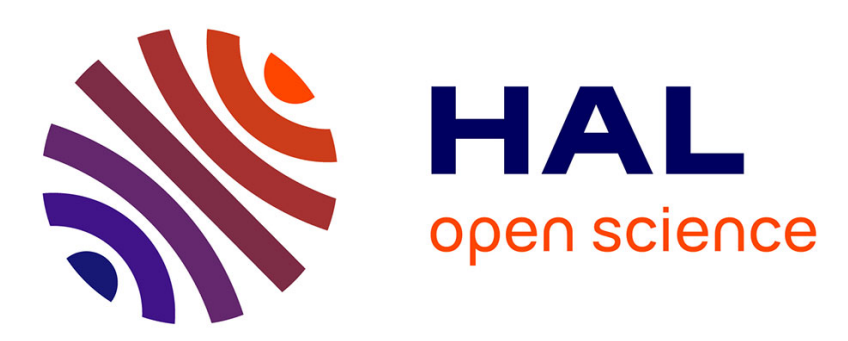

\title{
Oxidative dehydrogenation of ethyl lactate to ethyl pyruvate over vanadium and iron antimonates catalysts
}

J. M. M. Millet, M. Huchede, D. Morvan, R. Vera, V. Bellière-Baca, J.M.M.

Millet

\section{- To cite this version:}

J. M. M. Millet, M. Huchede, D. Morvan, R. Vera, V. Bellière-Baca, et al.. Oxidative dehydrogenation of ethyl lactate to ethyl pyruvate over vanadium and iron antimonates catalysts. Applied Catalysis A : General, 2021, 617, pp.118016. 10.1016/j.apcata.2021.118016 . hal-03385179

\author{
HAL Id: hal-03385179 \\ https://hal.science/hal-03385179
}

Submitted on 19 Oct 2021

HAL is a multi-disciplinary open access archive for the deposit and dissemination of scientific research documents, whether they are published or not. The documents may come from teaching and research institutions in France or abroad, or from public or private research centers.
L'archive ouverte pluridisciplinaire $\mathbf{H A L}$, est destinée au dépôt et à la diffusion de documents scientifiques de niveau recherche, publiés ou non, émanant des établissements d'enseignement et de recherche français ou étrangers, des laboratoires publics ou privés. 


\title{
Oxidative dehydrogenation of Ethyl lactate to Ethyl pyruvate over vanadium and iron antimonates catalysts
}

\author{
M. Huchede ${ }^{1}$, D. Morvan ${ }^{2}$, R. Vera ${ }^{1}$, V. Bellière-Baca ${ }^{2}$, J.M.M. Millet ${ }^{1 *}$ \\ ${ }^{1}$ Univ Lyon, Université Claude Bernard Lyon 1, CNRS, IRCELYON - UMR 5256, 2 Av. Albert \\ Einstein, 69626 Villeurbanne, France
}

${ }^{2}$ Adisseo, Antony Parc 2, 10 Place Général de Gaulle, 92160 Antony, France

* Corresponding author: jean-marc.millet@ircelyon.univ-lyon1.fr 


\begin{abstract}
The oxidative dehydrogenation of ethyl lactate to ethyl pyruvate, corresponding to the first step of a new process in the industrial production of methionine, has been investigated. Iron and vanadium antimonates were developed as catalysts, and were optimized to reach $87 \%$ conversion of ethyl lactate, with $88 \%$ selectivity to ethyl pyruvate, at only $275{ }^{\circ} \mathrm{C}$. The catalysts were characterized before and after catalytic testing, and in situ using various techniques, including X-ray diffraction (XRD), X-ray photoelectron spectroscopy (XPS), and XANES spectroscopy. The results show that neither the $\mathrm{Sb}^{3+} / \mathrm{Sb}^{5+}$ nor the $\mathrm{Fe}^{2+} / \mathrm{Fe}^{3+}$ redox couple were involved in the dehydrogenation of ethyl lactate, or in the catalysts re-oxidation. The active and selective catalytic sites correspond to surface $\mathrm{V}^{5+}$ species. These species should not be considered as part of the bulk oxide, but as supra-surface species whose surface content is monitored with the bulk composition.
\end{abstract}

Keywords: iron and vanadium antimonate, Ethyl lactate, Ethyl pyruvate, oxidation catalysts, oxidative dehydrogenation, molecular oxygen, keto vinyl acid 


\section{Introduction}

A considerable effort is currently being devoted to the development of new methionine derivatives, among which 2-Oxo-4-MethylthioButyric Acid (AOMB), also called 2-Keto-4Methylthio Butyric acid (KMB), lies at the nutritional crossroads of several forms of methionine, for which there is no known industrial production process. can be obtained from keto vinyl acid (KVA), by condensation with methanethiol (Fig. 1). While methanethiol is widely used for the industrial production of methionine, a single route for the synthesis of keto vinyl acid has been reported and patented [1]. This corresponds to the catalytic oxidation of but-3-ene-1,2-diol in the liquid phase, on noble metal catalysts supported on activated carbon, and in the presence of sodium hydroxide. This synthetic route is however difficult to industrialize, and uses an expensive starting material.

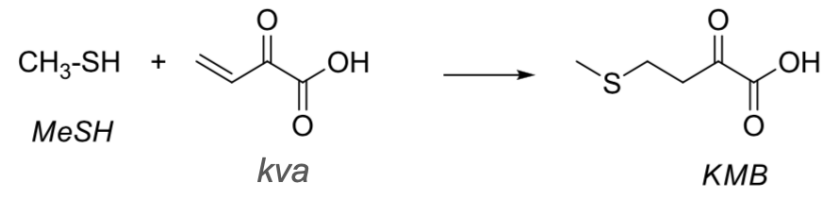

Fig. 1 : Addition reaction of methyl mercaptan with keto vinylic acid for KMB production.

The production of KVA from lactic, acid using gas-phase heterogeneous catalysis, is an attractive synthetic route. A process involving two consecutive steps can be implemented: these correspond to the oxidative dehydrogenation of lactic acid to pyruvic acid, followed by the aldolization of pyruvic acid using formaldehyde (Fig. 2).<smiles>CC(O)C(=O)O</smiles>

lactic acid

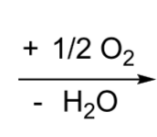<smiles>CC(=O)C(=O)O</smiles>

pyruvic acid

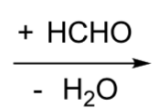<smiles>C=CC(=O)C(=O)O</smiles>

Fig. 2 : Oxidative dehydrogenation and aldolization reaction for the production of KVA. 
Alternatively, pyruvic acid could be used to produce KVA, with the advantage that the chain of ketone and acid groups is present in the target molecule. This chemical function is reactive, thanks to the presence of an enolisable function (the ketone function), which enables the aldolization reaction during the second stage of the process. Furthermore, pyruvic acid can be produced from lactic acid. From the industrial perspective, this would be an advantageous route since lactic acid costs approximately $1 \$$ per kilogram, whereas pyruvic acid is ten times more expensive [2].

However, when the entire process is considered, it may be preferable to start with ethyl lactate, and oxidatively dehydrogenate it to ethyl pyruvate, rather than using pyruvic acid. First, the two esters are much more stable than the corresponding acids, and the protection of the group could be advantageously retained for the second aldolization step in the process. The gas-phase oxidative dehydrogenation of ethyl lactate to ethyl pyruvate has been the subject of several studies, and several catalysts have been proposed, all of which have drawbacks in the context of an industrial application, as described in the following. The first catalyst used for this reaction was $\mathrm{VPO}_{\mathrm{x}} / \mathrm{SiO}_{2}$, with a $\mathrm{P} / \mathrm{V}$ molar ratio equal to 10, allowing a conversion of $90 \%$ and a selectivity of $60 \%$ to be achieved at $300^{\circ} \mathrm{C}$ [3]. However, the highly diluted flow of ethyl lactate gas needed for this reaction would be almost inconceivable for an industrial application. A tellurium and molybdenum mixed oxide catalyst was then described, with an even more efficient conversion of $80 \%$, and a $90 \%$ selectivity to ethyl pyruvate, at $300{ }^{\circ} \mathrm{C}$ [4]. However, the tellurium was progressively reduced to metallic tellurium and lost from the catalyst, leading to its inevitable and irreversible deactivation. Silver, in bulk or supported form, which is an efficient oxidative dehydrogenation catalyst, could have been used in view of its efficiency [5-7]. However, this efficiency appears to be limited, and has been observed only with a nearly explosive ethyl lactate gas mixture.

The present authors recently published a study describing the screening of approximately twenty oxide catalysts, which were used to promote various oxidative dehydrogenation reactions reported in the literature. This study revealed that the most suitable catalyst was phosphomolybdic polyoxometalate, with iron counter-cations [8]. These catalysts allow ethyl lactate to be produced at $77 \%$ conversion, with a $79 \%$ selectivity to ethyl pyruvate at $275^{\circ} \mathrm{C}$, under reaction conditions compatible with an 
industrial process. Although these catalysts are quite stable with time on stream, they were found to be extremely sensitive to any temporary change in reaction conditions, and were prone to irreversible deactivation.

In the present study, we report on the use of mixed vanadium and iron antimonates, for the oxidative dehydrogenation of ethyl lactate to ethyl pyruvate. Over the last thirty years, vanadium antimonate compounds, $\mathrm{VSbO}_{4}$, have been extensively studied as catalysts for the production of chemical intermediates, such as acrylonitrile or acrylic acid [9-11]. In an effort to improve the activity and selectivity of vanadium antimonate, considerable research has been devoted to the addition of various dopants inside the structure of the $\mathrm{VSbO}_{4}$ [12-15]. When introduced into $\mathrm{VSbO}_{4}, \mathrm{Al}, \mathrm{Ga}, \mathrm{Fe}$, $\mathrm{Ti}$, as well as Group VI transition metals such as W lead to solid solutions with a rutile structure, thus significantly modifying the activity and selectivity in all reactions of interest. In general, these effects are attributed to the isolation of active vanadium sites on the surface of the catalyst [16-18]. Currently, almost all of the vanadium antimonate catalysts described for propane (amm)oxidation are based on a sophisticated blend of several dopants: AlWVSbO, VSnSbO, UFeWSbO and FeVSbO, suggesting that other effects such as the formation or suppression of acid sites or the involvement of a redox couple (other than those of vanadium) in the re-oxidation of the catalysts, could be considered. The $\mathrm{Fe}_{\mathrm{x}} \mathrm{V}_{1-}$ ${ }_{x} \mathrm{SbO}_{4}$ system, in which $0<x<1$, has been studied for the oxidation of propane to acrylic acid, but also for the oxidative dehydrogenation of ethanol to acetaldehyde [19].

The influence of synthesis temperature and cationic composition on the properties of various catalysts, during the oxidative dehydrogenation of ethyl lactate, have been studied. These catalysts were characterized using techniques such as X-ray diffraction, Mössbauer and X-ray photoelectron spectroscopy, prior to and following catalytic testing, firstly to ensure that they were stable and secondly to explore the role of any redox couples intervening in the Mars and van Krevelen reaction mechanism. In order to validate the results of this analysis, in situ XANES spectroscopic characterization was also used under the same catalytic test conditions. 


\section{Experimental}

\subsection{Synthesis of the catalysts}

Two series of iron and vanadium antimonates were prepared according to two different protocols $[20,21]$. The first one of these corresponded to iron-rich solids. Typically, in the case of $\mathrm{Fe}_{0.85} \mathrm{~V}_{0.15} \mathrm{SbO}_{4}$, an aqueous solution $(100 \mathrm{~mL})$ containing $5.8 \mathrm{mmol}$ of $\mathrm{Fe}\left(\mathrm{NO}_{3}\right)_{3 .} .9 \mathrm{H}_{2} \mathrm{O}$ was stirred until complete dissolution. $1.0 \mathrm{mmol}$ of $\mathrm{NH}_{4} \mathrm{VO}_{3}$ and $3.4 \mathrm{mmol}$ of $\mathrm{Sb}_{2} \mathrm{O}_{3}$ were then added to the solution, and the suspension was maintained at $80{ }^{\circ} \mathrm{C}$ for $30 \mathrm{~min}$, following which the $\mathrm{pH}$ was adjusted to 3 using $\mathrm{NH}_{4} \mathrm{OH}(32 \%)$. The resulting solid was isolated by centrifugation, washed with distilled water $(2 \times 30 \mathrm{ml})$, dried for 12 hours at $90^{\circ} \mathrm{C}$, then calcined for 20 hours at $500^{\circ} \mathrm{C}$ and for 2 hours at $900^{\circ} \mathrm{C}$ in air $\left(100 \mathrm{ml} \cdot \mathrm{min}^{-1}, 5^{\circ} \mathrm{C} \cdot \mathrm{min}^{-1}\right)$. The second series corresponded to vanadium-rich compounds only. For $\mathrm{Fe}_{0.20} \mathrm{~V}_{0.80} \mathrm{SbO}_{4}$, an aqueous solution (150 ml) containing $11 \mathrm{mmol}$ of $\mathrm{NH}_{4} \mathrm{VO}_{3}$ and $2.7 \mathrm{mmol}$ of $\mathrm{Fe}\left(\mathrm{NO}_{3}\right)_{3 .} \cdot 9 \mathrm{H}_{2} \mathrm{O}$ was prepared and heated to $80^{\circ} \mathrm{C}$. After complete dissolution, $7 \mathrm{mmol}$ of $\mathrm{Sb}_{2} \mathrm{O}_{3}$ were added, and the resulting suspension refluxed for $18 \mathrm{~h}$ with stirring. The water was then evaporated under vacuum $(10 \mathrm{mbar})$ at $70^{\circ} \mathrm{C}$. The solid was dried for 12 hours at $90^{\circ} \mathrm{C}$, then calcined for 3 hours at $200^{\circ} \mathrm{C}$ and for 2 hours at $700^{\circ} \mathrm{C}$ in air $\left(100 \mathrm{ml} \cdot \mathrm{min}^{-1}, 5^{\circ} \mathrm{C} \cdot \mathrm{min}^{-1}\right)$. In order to study the influence of synthesis temperature on the catalytic properties, these solids were also heat treated for 2 hours at $900^{\circ} \mathrm{C}$ in air $\left(100 \mathrm{ml} \cdot \mathrm{min}^{-1}, 5^{\circ} \mathrm{C} \cdot \mathrm{min}^{-1}\right)$. The compounds of the two series were referred to their vanadium cationic composition. For example, VFeSbO-0.8 corresponds to the solid with the formula $\mathrm{V}_{0.8} \mathrm{Fe}_{0.2} \mathrm{SbO}_{4}$.

\subsection{Characterization of catalysts}

Elementary analyses of the synthesized antimonates were obtained from ICP-OES spectra (ACTIVA/Jobin Yvon), following acidic dissolution. Their specific surface area was measured by 
applying the single-point BET method. Thermogravimetric analyses (TGA) were performed with a TGA/DSC 1 STARe System from Mettler Toledo. Around $8 \mathrm{mg}$ of the samples were sealed in $100 \mathrm{ml}$ $\mathrm{Al}$ crucibles inside a glove-box, and heated under an argon atmosphere at a heating rate of $5^{\circ} \mathrm{C} \min ^{-1}$. XRD patterns of the samples were measured in Bragg-Brentano geometry with a Bruker D8 Advance diffractometer (using $\mathrm{CuK}_{\alpha}$ radiation at $\lambda=0.15406 \mathrm{~nm}$ ), equipped with a Bruker Lynxeye detector. The TOPAS-4.2 program was used to calculate the relative phase content in the reduced samples and unit cell parameters, and scanning electron microscopy (SEM) provided information on the morphology, structure and composition of the solids. The SEM images were recorded on an ESEMFEG FEI XL 30 microscope, under ultrahigh vacuum. Before each analysis, the powders are covered with a film of pulverized gold in order to avoid charge effects. The Mössbauer spectra of the synthesized samples were obtained with a constant acceleration spectrometer, described elsewhere [22]. Samples of $2 \mathrm{GBq}^{57} \mathrm{Co} / \mathrm{Rh}$ and pure $\alpha$-Fe were used as the source and reference, respectively.

The XPS analyses of surface elemental composition were carried out with a Kratos Axis Ultra DLD spectrometer, using a hemispherical analyzer working under vacuum at $5.10^{-8} \mathrm{~Pa}$ and a monochromatic beam of photons $\mathrm{X}$ from $\mathrm{Al} \mathrm{K} \alpha$ radiation $(1486.6 \mathrm{eV})$. The measured bonding energies were corrected with respect to the $\mathrm{C} 1 \mathrm{~s}$ signal at $284.6 \mathrm{eV}$. For all quantitative analyses, the spectra were fitted by Voigt-type functions, using SPX processing software (vision 2.2.6 Kratos). The surface composition and oxidation states of each of the constituent elements were determined by analyzing the core levels Fe2p, Sb4d and 3d, V2p, O1s and C1s. Antimony is characterized by a main peak corresponding to the $3 \mathrm{~d}$ level at $531-532 \mathrm{eV}$, and a secondary line corresponding to $4 \mathrm{~d}$ at 35 $36 \mathrm{eV}$. In the majority of studies of antimony-based compounds and vanadium antimonates, the Sb3d line is used [19, 23, 24]. Indeed, the intensity of the signal corresponding to this orbital is twenty times greater than that of 4d, as shown in Fig. S1. Among the components of the main line of the $3 d$ orbital of $\mathrm{Sb}$, the use of $\mathrm{Sb3d} \mathrm{d}_{3 / 2}$ at $541 \mathrm{eV}$ was preferred to $\mathrm{Sb} 3 \mathrm{~d}_{5 / 2}$, due to the superposition of the $1 \mathrm{~s}$ oxygen signal at 531-532 eV [25] (Fig. S2). A study of the $\mathrm{Sb}_{3 / 2}$ signal produced by mixed-valence compounds has shown that very small changes in ionization energy, of the order of $0.5 \mathrm{eV}$, are associated with the $\mathrm{Sb}^{3+}$ and $\mathrm{Sb}^{5+}$ oxidation states [26]. In addition, by studying the decomposition of 
the $\mathrm{Sb}_{3} \mathrm{~d}_{3 / 2}$ signal of mixed valence antimony oxides, it has been shown that the $\mathrm{Sb}^{5+}$ and $\mathrm{Sb}^{3+}$ signals are difficult to separate, and that it is challenging to determine the individual atomic concentrations of each of these two species $[27,28]$. On the other hand, a study of the Sb4d level at $34-35 \mathrm{eV}$ shows that it is straightforward to distinguish between the signals corresponding to its two oxidation states. For all of these reasons, the Sb4d signal was initially studied to determine whether $\mathrm{Sb}^{3+}$ and $\mathrm{Sb}^{5+}$ coexist in the same sample. If only one oxidation state was detected, it would be preferable to use the Sb3d signal for the quantification of this element, due to the improved accuracy that could be expected from its considerably higher (20x) intensity. As an example, the presence of a single oxidation state is characterized by a "spin-orbit" of 1.2-1.3 eV, with an area ratio of 0.66 between the two signals.

Iron edge is characterized by two peaks: the $2 \mathrm{p}$ level, located at $709-711 \mathrm{eV}$ for $\mathrm{Fe} 2 \mathrm{p}_{3 / 2}$, and at $722-724 \mathrm{eV}$ for $\mathrm{Fe} 2 \mathrm{p}_{1 / 2}$. The various oxidation states of iron are characterized mainly by the presence of a signal at $709.3 \mathrm{eV}$, corresponding to the $\mathrm{Fe}^{2+}$ ion, and a second signal at $711.4 \mathrm{eV}$, corresponding to the $\mathrm{Fe}^{3+}$ ion. XPS spectral analysis thus allows each of these species to be distinguished and quantified. The satellite identified at $717.6-717.7 \mathrm{eV}$ is characteristic of the $\mathrm{Fe}^{2+}$ ion, whereas the satellite identified at $718.8-719.9 \mathrm{eV}$ is characteristic of the $\mathrm{Fe}^{3+}$ ion [29]. In the case of compounds with a mixed valence, containing both $\mathrm{Fe}^{2+}$ and $\mathrm{Fe}^{3+}$ ions, the signals corresponding to the satellites of each of these species are superimposed, thus decreasing the accuracy of their quantification.

In the case of vanadium, its main line corresponds to the $2 p$ level, which is characterized by binding energies between 515 and $517 \mathrm{eV}$ for $\mathrm{V} 2 \mathrm{p}_{3 / 2}$, and between 522 and $524 \mathrm{eV}$ for $\mathrm{V} 2 \mathrm{p}_{1 / 2}$. It can be difficult to analyze vanadium on the surface of iron and in vanadium antimonates, because it can be present in three different oxidation states. High-resolution analysis of the V2p signal can be used to quantify each of these species. Two separate regions are thus defined for $V 2 p_{3 / 2}$ and $V 2 p_{1 / 2}$. As it is not straightforward to analyze the continuous background of the $\mathrm{V} 2 \mathrm{p}_{1 / 2}$ signal at $522 \mathrm{eV}$, which is strongly affected by the presence of the $\mathrm{O} 1 \mathrm{~s}$ signal at $531 \mathrm{eV}$, only the structure of level $\mathrm{V} 2 \mathrm{p}_{3 / 2}$ at 515 $517 \mathrm{eV}$ is presented here. XPS analysis of the $\mathrm{V} 2 \mathrm{p}_{3 / 2}$ signal produced by vanadium oxide compounds of different valences reveals significant changes in bond energy. When several oxidation states coexist 
in the same compound, small changes in position are nevertheless observed, with respect to the pure compound [30].

The XAS measurements described in the present study were carried out at the SOLEIL synchrotron, on the ROCK beamline (Rocking Optics for Chemical Kinetics), at the K-edge of iron $(7112.0 \mathrm{eV})$ and vanadium $(5465.1 \mathrm{eV})$, and at the $\mathrm{L}_{1}$-edge of antimony $(4698.3 \mathrm{eV})$. All analyses were performed in the transmission mode, in Quick-EXAFS (QEXAFS), allowing the acquisition of 4 spectra per second. For the ex-situ analyses, the samples were first diluted in $10 \%$ to $15 \%$ of $\mathrm{BN}$, and then pelletized. In order to obtain the best possible response from each element, the quantity of catalyst was optimized and 2 pellets were made for each sample (one for the analysis of iron, and the other for that of vanadium and antimony). In-situ studies were also carried out, in order to monitor any change in oxidation state in the bulk of the catalyst under catalysis conditions. By optimizing the detectors, it was possible to simultaneously analyze iron, vanadium and antimony in the same sample. The in-situ cell could be used for studies at atmospheric pressure and at temperatures as high as $600^{\circ} \mathrm{C}$ [31]. The sample holder comprises a central element, as well as front and rear plates with small apertures designed to permit transmission of the X-ray beam. In order to ensure the air-tightness of the cell under reaction flow, two $500 \mu \mathrm{m}$ thick graphite sheets were inserted between the rear plate and the central element, and just one graphite sheet was inserted between the front plate and the central element. However, as these sheets absorb a high proportion of X-ray photons at the $\mathrm{L}_{1}$-edge of $\mathrm{Sb}$, it was not possible to record the spectra of antimony under these conditions. For this reason, all of the graphite sheets were perforated in their center, in order to increase the number of transmitted photons, and a $50 \mu \mathrm{m}$ thick Kapton window was added on each side of the central element, to keep the sample inside the $(5 \times 8 \mathrm{~mm})$ cell. As Kapton has a low thermal resistance, the spectra were only recorded beyond $250^{\circ} \mathrm{C}$. These modifications made it possible to carry out a in situ study of the oxidation state of antimony at the $\mathrm{L}_{1}$-edge, as previously reported [32]. Two to three $\mathrm{mg}$ of the catalyst was diluted in boron nitride ( $10 \%$ by mass), then placed in the reactor and heated to $250^{\circ} \mathrm{C}$ under air flow $\left(7 \mathrm{~mL} . \mathrm{min}^{-}\right.$ $\left.{ }^{1}, 5^{\circ} \mathrm{C} \cdot \mathrm{min}^{-1}\right)$, prior to vaporization of the ethyl lactate. The composition of the reaction flow was almost identical to that used for the evaluation of catalytic properties: EtLA/ inert/ $\mathrm{O}_{2}$ : 12.3/ 66.4/ 
19.3. spectra were recorded for a period of $15 \mathrm{~min}$ at each edge, leading to a total test duration ranging between $30 \mathrm{~min}$ and $2 \mathrm{~h}$. Measurements were also carried out at room temperature, prior to heating and after cooling.

\subsection{Catalysts testing}

The catalytic properties of the synthesized compounds were evaluated using the same setup as that described in previous studies [8]. Reactions were carried out at temperatures ranging between 250 and $400^{\circ} \mathrm{C}$, with a gas mixture composition corresponding to $\mathrm{EtLA} / \mathrm{O}_{2} /$ inert $=12.3 / 18.4 / 69.3$, with $\mathrm{m}_{\text {cat }}=250 \mathrm{mg}^{-1}, \mathrm{PPH}=0.1 \mathrm{~h}$ and $\mathrm{V}_{\text {total }}=65 \mathrm{~mL} \cdot \mathrm{min}^{-1}$. After being diluted in SiC alpha $\left(\mathrm{m}_{\mathrm{SiC}} \mathrm{d}\right.$ $\mathrm{m}_{\text {cat }}=2$ ), the catalyst remained stable for longer than $22 \mathrm{~h}$, under reaction conditions. The condensable reaction products were trapped in acetonitrile at $0-2^{\circ} \mathrm{C}$ and analyzed on a Shimadzu GC-2014 chromatograph, equipped with a Nukol type $(30 \mathrm{~m} \times 0.53 \mathrm{~mm} \times 0.5 \mu \mathrm{m})$ polar capillary column. Tetrahydrofuran (THF) was used as an external standard. The volatiles were characterized on line with a $\mu$ GC-TCD analyzer (SRA R3000 chromatograph equipped with a molecular sieve, a Porapak Q and a TCD detector). Nitrogen was used as an internal standard. The carbon balances were greater than $98 \%$, and a blank test showed no conversion of ethyl lactate up to $350^{\circ} \mathrm{C}$.

\section{Results}

\subsection{Characterization of the synthesized catalysts}

The measured molar ratios and surface areas of the synthesized VFeSbO catalysts are provided in Table 1. The chemical analysis of these solids is found to be in good agreement with the theoretical formulas proposed in the first published studies of these catalysts [15,19, 22]. Following the introduction of iron, the $\mathrm{V}^{4+}$ content decrease continuously until $\mathrm{V}^{3+}$ cations only were observed, with no remaining cationic vacancy. The BET surface areas were rather low, and comparable for all of 
the solids. They were found to decrease slightly when the temperature of the final heat treatment was increased.

Table 1: Results of chemical analyses and specific surface area measurements.

\begin{tabular}{|c|c|c|c|c|}
\hline \multirow[t]{2}{*}{ Catalysts } & \multicolumn{2}{|c|}{ Molar ratio } & \multicolumn{2}{|r|}{ SSA $\left(m^{2} \cdot g^{-1}\right.$} \\
\hline & $\mathrm{V} /(\mathrm{V}+\mathrm{Fe})$ & $(\mathrm{V}+\mathrm{Fe} / \mathrm{Sb})$ & ht $700^{\circ} \mathrm{C}$ & ht $900^{\circ} \mathrm{C}$ \\
\hline $\mathrm{VSbO}_{4}$ & 1.00 & 0.91 & 13 & 10 \\
\hline $\mathrm{V}_{0.8} \mathrm{Fe}_{0.2} \mathrm{SbO}_{4}$ & 0.80 & 0.95 & 12 & 10 \\
\hline $\mathrm{V}_{0.6} \mathrm{Fe}_{0.4} \mathrm{SbO}_{4}$ & 0.59 & 0.92 & 18 & 11 \\
\hline $\mathrm{V}_{0.35} \mathrm{Fe}_{0.65} \mathrm{SbO}_{4}$ & 0.34 & 0.95 & & 11 \\
\hline $\mathrm{V}_{0.15} \mathrm{Fe}_{085} \mathrm{SbO}_{4}$ & 0.13 & 0.96 & & 11 \\
\hline
\end{tabular}

The X-ray diffraction patterns of the solids revealed just one, well-crystallized rutile-type phase for all prepared samples (Fig. 3 and 4). The influence of calcination temperature on the structure was studied for $\mathrm{V}_{0.35} \mathrm{Fe}_{0.65} \mathrm{SbO}_{4}$ (Fig. 3). It can be seen that the main diffraction lines of the rutile phase were detected above $350^{\circ} \mathrm{C}$, and that an increase in calcination temperature, from 700 to $900{ }^{\circ} \mathrm{C}$, results in improved crystallinity of the solid and an increase in the size of the crystallites.

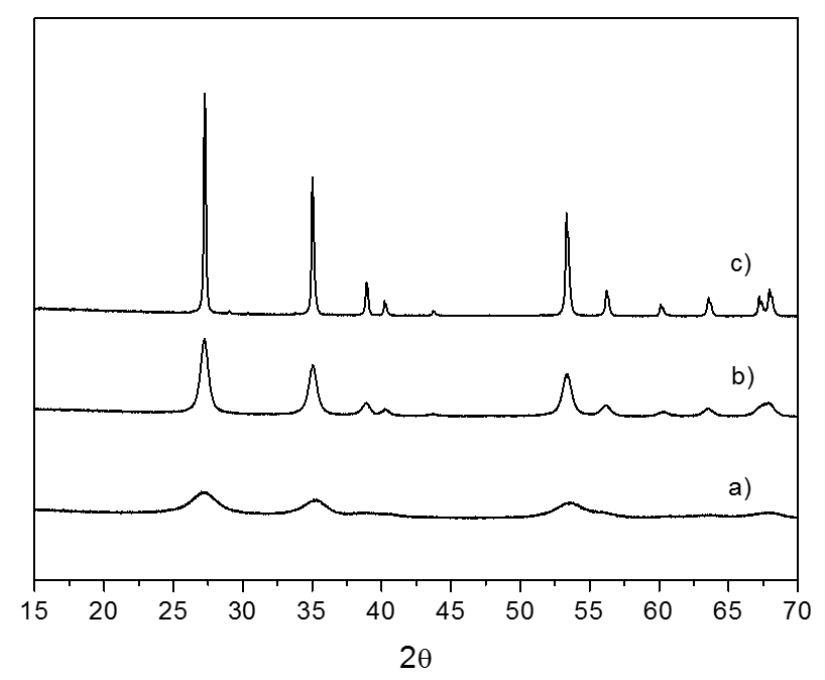

Fig. 3: $\mathrm{X}$-ray diffraction patterns of the $\mathrm{V}_{0.35} \mathrm{Fe}_{0.65} \mathrm{SbO}_{4}$ mixed iron and vanadium antimonate catalyst, treated at different temperatures: a) $350^{\circ} \mathrm{C}$ b) $700^{\circ} \mathrm{C}$ and c) $900^{\circ} \mathrm{C}$. 
Contrary to the results reported in some studies, crystalline phases of $\mathrm{Fe}_{2} \mathrm{O}_{3}$ and $\mathrm{Sb}_{2} \mathrm{O}_{4}$ were not detected. The calculated unit cell parameters are listed in Table 2.

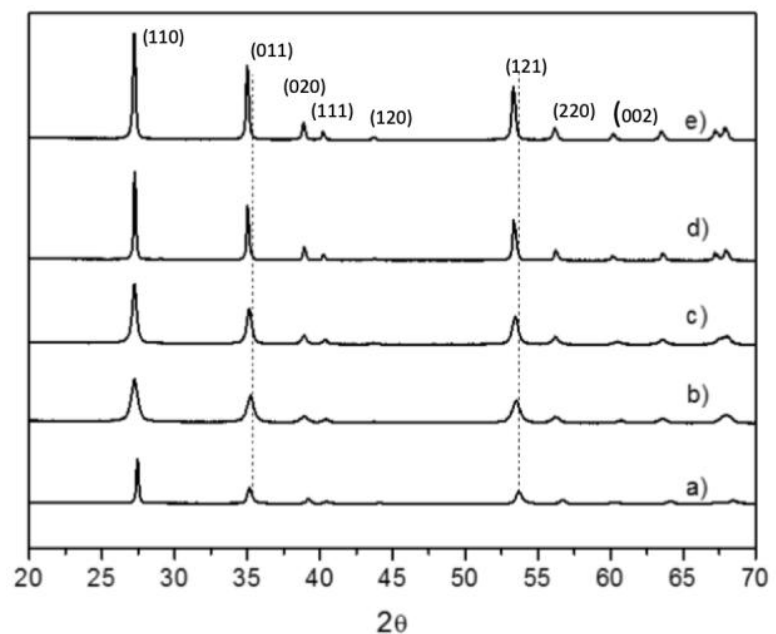

Fig. 4: X-ray diffraction patterns of mixed iron and vanadium antimonates: a) $\mathrm{VSbO}_{4}$, b) $\mathrm{V}_{0.8} \mathrm{Fe}_{0.2} \mathrm{SbO}_{4}, \mathrm{c}$ ) $\mathrm{V}_{0.4} \mathrm{Fe}_{0.60} \mathrm{SbO}_{4}$, d) $\mathrm{V}_{0.35} \mathrm{Fe}_{0.65} \mathrm{SbO}_{4}$, e) $\mathrm{VxFexSbO}_{4}$.

Table 2: Evolution of the unit cell parameters of the $\mathrm{V}_{1-\mathrm{x}} \mathrm{Fe}_{\mathrm{x}} \mathrm{VO}_{4}$ as a function of its composition.

\begin{tabular}{ccccccc}
\hline Unit cell parameters & \multicolumn{7}{c}{$\mathbf{x}$ in $\mathbf{V}_{\mathbf{1 - \mathbf { x }}} \mathbf{F e}_{\mathbf{x}} \mathbf{V} \mathbf{O}_{\mathbf{4}}$} \\
& 0.0 & 0.2 & 0.3 & 0.4 & 0.65 & 0.85 \\
\hline & & & & & & \\
$\mathrm{a}(\mathrm{nm})$ & $4.6222(3)$ & $4.6285(3)$ & $4.6261(4)$ & $4.6261(3)$ & $4.6251(1)$ & $4.6295(1)$ \\
$\mathrm{c}(\mathrm{nm})$ & $3.0468(3)$ & $3.0442(2)$ & $3.0512(3)$ & $3.0601(2)$ & $3.07474(9)$ & $3.0739(2)$ \\
& & & & & & \\
\hline
\end{tabular}

One compound rich in vanadium, and another rich in iron, were studied using scanning electron microscopy, with the resulting images as shown in Fig. 5. The vanadium-rich solid was composed of 50 to $100 \mathrm{~nm}$ diameter particles, which agglomerated to form grains ranging between 15 to $20 \mu \mathrm{m}$ in size. In the case of the iron-rich compound, the particles ranged between 100 and $200 \mathrm{~nm}$ in diameter, and these did not appear to be clearly agglomerated into larger grains. The observed disparity in particle size can be attributed to the different calcination temperatures applied to these two compounds. 


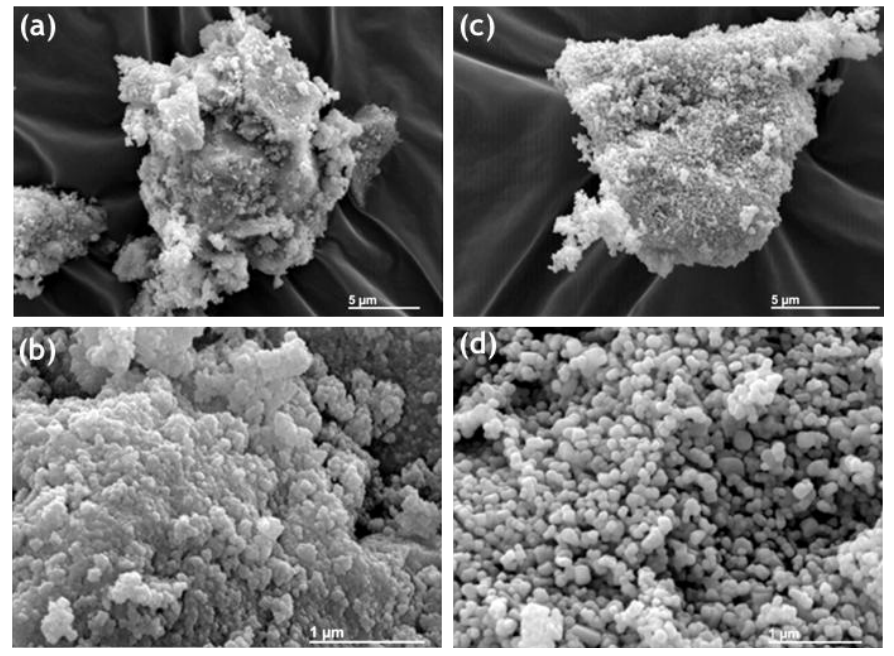

Fig. 5: SEM images of two catalysts: $\mathrm{V}_{0.8} \mathrm{Fe}_{0.2} \mathrm{SbO}_{4}$ (a and b) and $\mathrm{V}_{0.35} \mathrm{Fe}_{0.65} \mathrm{SbO}_{4}$ (c and d).

\subsection{Test of catalyst in ethyl lactate oxidative dehydrogention}

The catalytic properties of the compounds synthesized at 700 and $900^{\circ} \mathrm{C}$ were evaluated for the oxidative dehydrogenation reaction of ethyl lactate, under the standard operating conditions described in the experimental section, which are compatible with a large-scale industrial process. The results are presented in Tables 3 and 4, and illustrated in Fig. 6. Iron antimonates are thus found to be active and selective catalysts. Their activity reaches a maximum in compositions having a $\mathrm{V} /(\mathrm{Fe}+\mathrm{V})$ ratio equal to 0.8 . This maximum was observed for catalysts prepared at $900^{\circ} \mathrm{C}$. However, the catalysts prepared at $700^{\circ} \mathrm{C}$ appeared to be less active in terms of the intrinsic rates of ethyl lactate transformation (Table 4 and Fig 6).

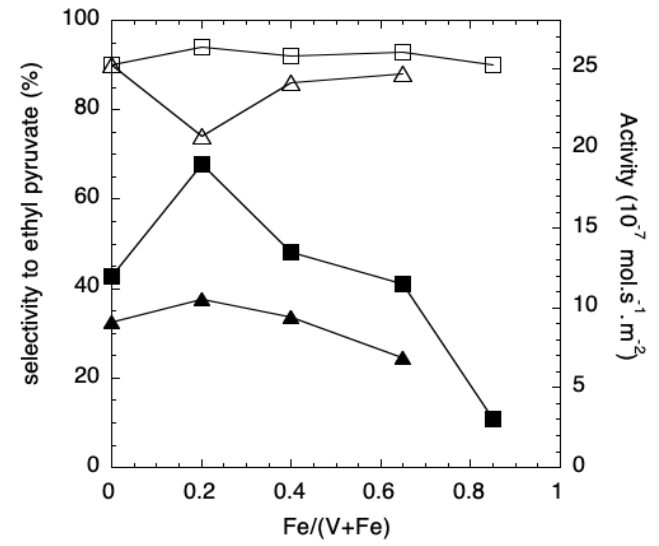


Fig. 6 : Rate of ethyl lactate conversion (full symbols) and selectivity to ethyl pyruvate (empty symbols) as a function of the iron content in the $\mathrm{V}_{1-\mathrm{x}} \mathrm{Fe}_{\mathrm{x}} \mathrm{SbO}_{4}$ catalysts prepared at $700^{\circ} \mathrm{C}$ (triangles) and at $900^{\circ} \mathrm{C}$ (squares); testing were performedat $250^{\circ} \mathrm{C}$, under standard conditions.

For all catalysts, the selectivity to ethyl pyruvate remains constant when the temperature is increased to $275^{\circ} \mathrm{C}$. However, the selectivity decreases at higher temperatures to the advantage of all of the other by-products, which are formed by the decomposition of both ethyl lactate and ethyl pyruvate [8]. The composition of these catalysts has no significant influence on their selectivity, with the exception of $\mathrm{V}_{0.8} \mathrm{Fe}_{0.2} \mathrm{SbO}_{4}$ treated at $700^{\circ} \mathrm{C}$, for which a singular decrease in selectivity was observed, in favor of over-oxidation products.

The influence of the oxygen/ethyl lactate ratio on the $\mathrm{V}_{0.6} \mathrm{Fe}_{0.4} \mathrm{SbO}_{4}$ catalyst, prepared at $700^{\circ} \mathrm{C}$, was studied at $250^{\circ} \mathrm{C}$ (Fig. 7). The partial pressure of ethyl lactate was held constant $(12.5 \mathrm{kPa})$, while that of oxygen was varied $\left(65 \mathrm{~mL} \cdot \mathrm{min}^{-1}\right)$, at constant total volume of gas. It can be seen that an increase in the partial pressure of oxygen has a positive effect on the catalytic activity, up to $\mathrm{O}_{2} / \mathrm{EtLA}=1.5$, beyond which conversion to ethyl lactate remains constant. In Fig. 7a, it can be seen that an increasing partial pressure of oxygen leads to a decrease in selectivity to ETLA, in favor of the production of over-oxidation products such as acetic acid and $\mathrm{CO}_{2}$ (Fig. 7b). Under these experimental conditions, the partial order of the reaction with respect to oxygen is 0 (Fig. S3). The rate of consumption of ethyl lactate is thus independent of the partial pressure of oxygen, and the catalyst reoxidation step is not the limiting step of the reaction.
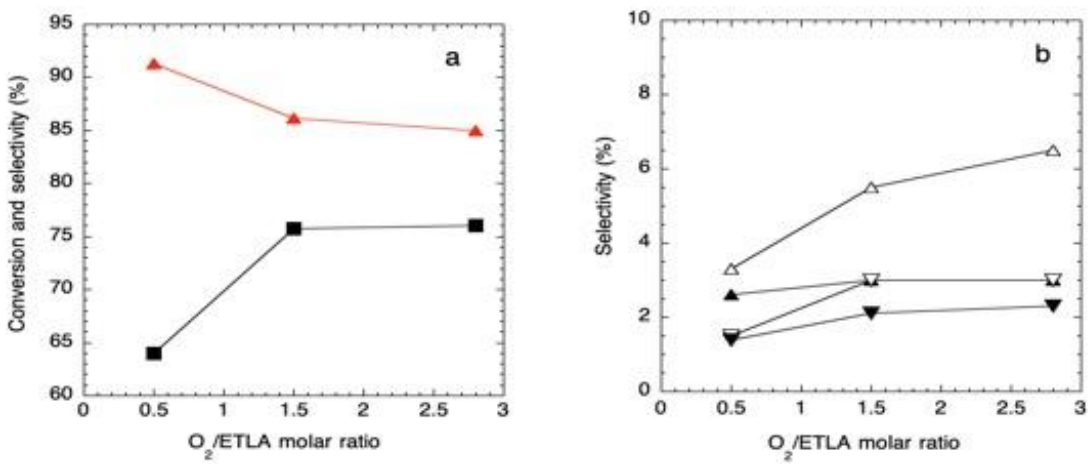

Fig. 7 : Variations in (a) rate of ethyl lactate conversion ( $\mathbf{\square})$ and selectivity to ethyl pyruvate ( $\Delta$ ), and (b) selectivity to by-products, as a function of the $\mathrm{O}_{2}$ to ethyl lactate molar ratio at $250^{\circ} \mathrm{C}$, under standard conditions, $(\triangle) \mathrm{CO}_{2},(\mathbf{\Delta})$ ethanol $(\boldsymbol{\nabla})$ acetic acid, $(\nabla)$ acetaldehyde. 
The stability of the catalysts was studied by testing them for $72 \mathrm{~h}$ at $250^{\circ} \mathrm{C}$, under standard conditions.

No deactivation or change in selectivity was observed for any of them. They were also heated to $350^{\circ} \mathrm{C}$ for 1 hour, then cooled down to $250^{\circ} \mathrm{C}$, with no measurable change in their catalytic properties.

Table 3: Results from testing of several different catalysts prepared at $900^{\circ} \mathrm{C}$, under standard reaction conditions. EtPa: Ethyl Pyruvate, ACHO: acetaldehyde, AcA: acetic acid.

\begin{tabular}{|c|c|c|c|c|c|c|c|c|}
\hline \multirow{3}{*}{ Catalysts } & \multirow{3}{*}{$\begin{array}{c}\text { Temp. } \\
\left({ }^{\circ} \mathbf{C}\right)\end{array}$} & \multirow{3}{*}{$\begin{array}{c}\text { Conversion } \\
(\%)\end{array}$} & \multicolumn{5}{|c|}{ Selectivity } & \multirow{3}{*}{$\begin{array}{l}\text { Yield } \\
(\%)\end{array}$} \\
\hline & & & & & $\%)$ & & & \\
\hline & & & EtPA & $\mathrm{ACHO}$ & $\mathrm{CO}_{2}$ & Ethanol & AcA & \\
\hline $\mathrm{VSbO}_{4}$ & 250 & 11.2 & 92.0 & 2.0 & 2.1 & 3.2 & 1.6 & 11.1 \\
\hline \multirow{3}{*}{$\mathrm{V}_{0.8} \mathrm{Fe}_{0.2} \mathrm{SbO}_{4}$} & 250 & 18.0 & 95.2 & 1.4 & 1.6 & 1.6 & 0.0 & 17.1 \\
\hline & 275 & 52.5 & 94.0 & 1.7 & 1.9 & 2.2 & 0.0 & 48.9 \\
\hline & 300 & 87.3 & 87.6 & 2.2 & 4.1 & 3.9 & 1.9 & 76.5 \\
\hline \multirow{3}{*}{$\mathrm{V}_{0.6} \mathrm{Fe}_{0.4} \mathrm{SbO}_{4}$} & 250 & 58.0 & 91.9 & 1.5 & 2.6 & 2.5 & 1.5 & 53.3 \\
\hline & 275 & 80.3 & 89.6 & 1.7 & 3.3 & 3.5 & 1.8 & 71.9 \\
\hline & 300 & 94.6 & 86.1 & 2.1 & 4.7 & 4.6 & 2.4 & 81.5 \\
\hline \multirow[t]{3}{*}{$\mathrm{V}_{0.35} \mathrm{Fe}_{0.65} \mathrm{SbO}_{4}$} & 250 & 54.8 & 92.6 & 1.8 & 2.1 & 3.4 & 0.0 & 57.2 \\
\hline & 275 & 85.8 & 86.3 & 2.6 & 2.8 & 5.4 & 2.8 & 74.0 \\
\hline & 300 & 88.7 & 81.9 & 3.0 & 4.7 & 6.9 & 3.3 & 72.6 \\
\hline \multirow[t]{3}{*}{$\mathrm{V}_{0.15} \mathrm{Fe}_{085} \mathrm{SbO}_{4}$} & 250 & 36.6 & 90.3 & 1.9 & 3.5 & 4.1 & 0.0 & 33.0 \\
\hline & 275 & 52.8 & 86.7 & 2.5 & 3.8 & 5.1 & 1.8 & 45.8 \\
\hline & 300 & 69.8 & 81.8 & 3.8 & 5.4 & 6.6 & 2.3 & 57.1 \\
\hline
\end{tabular}

Table 4: Results of catalytic testing of the catalysts prepared at $700^{\circ} \mathrm{C}$ and tested under standard reaction conditions. EtPa: Ethyl Pyruvate, ACHO: acetaldehyde, AcA: acetic acid.

\begin{tabular}{|c|c|c|c|c|c|c|c|c|}
\hline \multirow[t]{3}{*}{ Catalysts } & \multirow{3}{*}{$\begin{array}{l}\text { Temp. } \\
\left({ }^{\circ} \mathrm{C}\right)\end{array}$} & \multirow{3}{*}{$\begin{array}{l}\text { Conversion } \\
\qquad(\%)\end{array}$} & \multicolumn{5}{|c|}{ Selectivity. } & \multirow{2}{*}{$\begin{array}{l}\text { Yield } \\
(\%)\end{array}$} \\
\hline & & & & & $\%)$ & & & \\
\hline & & & EtPA & $\mathrm{ACHO}$ & $\mathrm{CO}_{2}$ & Ethanol & $\mathrm{AcA}$ & \\
\hline \multirow[t]{3}{*}{$\mathrm{VSbO}_{4}$} & 225 & 37.4 & 93.5 & 1.2 & 2.0 & 3.2 & 1.1 & 35.0 \\
\hline & 250 & 51.5 & 90.0 & 1.5 & 3.6 & 3.2 & 1.6 & 46.4 \\
\hline & 285 & 69.9 & 79.1 & 4.5 & 7.8 & 5.3 & 3.2 & 54.6 \\
\hline \multirow[t]{3}{*}{$\mathrm{V}_{0.8} \mathrm{Fe}_{0.2} \mathrm{SbO}_{4}$} & 225 & 40.5 & 89.9 & 1.8 & 4.0 & 2.6 & 1.5 & 36.4 \\
\hline & 250 & 51.8 & 73.8 & 5.3 & 9.7 & 4.7 & 3.5 & 38.2 \\
\hline & 285 & 67.5 & 38.5 & 17.2 & 25.2 & $9.9^{\mathrm{a}}$ & 9.2 & 26.0 \\
\hline \multirow[t]{3}{*}{$\mathrm{V}_{0.6} \mathrm{Fe}_{0.4} \mathrm{SbO}_{4}$} & 220 & 49.2 & 89.8 & 1.7 & 4.0 & 2.9 & 1.5 & 44.2 \\
\hline & 250 & 75.8 & 86.2 & 2.7 & 4.9 & 4.0 & 2.0 & 65.3 \\
\hline & 275 & 84.8 & 74.3 & 5.3 & 11.6 & 5.1 & 3.4 & 63.0 \\
\hline
\end{tabular}

\footnotetext{
${ }^{\mathrm{a}}$ ethanol $8.6 \%+$ ethylene $1.3 \%$
}

\subsection{Study of elemental oxidation states in fresh and used catalysts}


The test reactions described here involved the so-called "Mars and van Krevelen" mechanism, which requires a redox reaction at the surface or in the bulk of the catalysts. Their three constituent elements form redox couples, which are thought to be active in reactions of the same type, in other types of catalyst. It was therefore interesting to determine which of these couples were involved in the studied reaction. Various techniques were thus used to characterize the catalysts, before and after catalytic testing. Before presenting the results of these characterizations, it is important to note that no changes were observed in the X-ray diffractograms after catalytic testing.

The $\mathrm{V}_{0.8} \mathrm{Fe}_{0.2} \mathrm{SbO}_{4}$, and $\mathrm{V}_{0.4} \mathrm{Fe}_{0.60} \mathrm{SbO}_{4}$ samples were characterized using ${ }^{57} \mathrm{Fe}$ Mössbauer spectroscopy, before and after catalytic testing (Fig. 8), and the recorded spectra were fitted with one quadrupolar doublet, characterized by an isomeric shift equal to $0.37 \pm 0.02 \mathrm{~mm} \mathrm{~s}^{-1}$, and a quadrupolar splitting of $0.21 \pm 0.02 \mathrm{~mm} \mathrm{~s}^{-1}$ (Table 5). These hyperfine parameters are characteristic of ferric cations in an octahedral coordination.
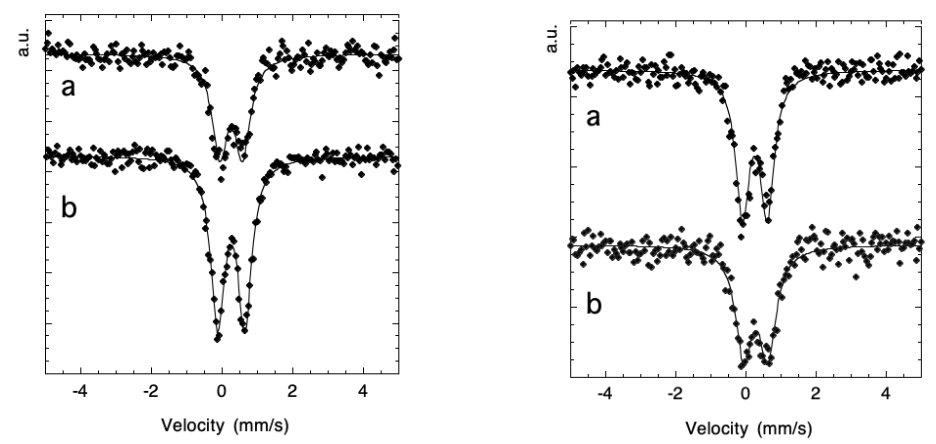

Fig. 8: ${ }^{57} \mathrm{Fe}$ Mössbauer absorption spectra of the $\mathrm{V}_{0.8} \mathrm{Fe}_{0.2} \mathrm{SbO}_{4}$, and $\mathrm{V}_{0.4} \mathrm{Fe}_{0.60} \mathrm{SbO}_{4}$ samples before and after catalytic testing. The solid lines are phenomenological fits.

Table 5: Hyperfine parameters computed from the spectra recorded at $25^{\circ} \mathrm{C}$ for two catalyst samples $\left(\mathrm{V}_{0.8} \mathrm{Fe}_{0.2} \mathrm{SbO}_{4}\right.$, and $\left.\mathrm{V}_{0.4} \mathrm{Fe}_{0.60} \mathrm{SbO}_{4}\right)$, before and after testing.

\begin{tabular}{llcc}
\hline Catalyst & & $\delta\left(\mathrm{mm} . \mathrm{s}^{-1}\right)$ & $\Delta\left(\mathrm{mm} . \mathrm{s}^{-1}\right)$ \\
\hline $\mathrm{V}_{0.6} \mathrm{Fe}_{0.4} \mathrm{SbO}_{4}$ & before test & 0.39 & 0.70 \\
$\mathrm{~V}_{0.6} \mathrm{Fe}_{0.4} \mathrm{SbO}_{4}$ & after test & 0.39 & 0.71 \\
$\mathrm{~V}_{0.35} \mathrm{Fe}_{0.65} \mathrm{SbO}_{4}$ & before test & 0.38 & 0.71 \\
$\mathrm{~V}_{0.35} \mathrm{Fe}_{0.65} \mathrm{SbO}_{4}$ & after test & 0.35 & 0.69 \\
\hline
\end{tabular}


The oxidation state of iron appeared to be the same, before and after catalytic testing, in both rich and poor vanadium-containing catalysts, suggesting that the $\mathrm{Fe}^{3+} / \mathrm{Fe}^{2+}$ redox couple was not involved in the reaction.

Several of the catalysts were characterized by XPS, in the majority of cases following, although in some cases prior to catalytic testing, in order to determine their surface oxidation states and the surface relative proportions of their constituent elements. All of the measurements revealed spectral peaks corresponding to the constituting elements only (Fig. S4). The surface cationic ratios calculated from the spectral analyses are presented in Table 6, and the binding energies corresponding to the fitted peaks are listed in Table S1.

Table 6: Surface elementary cationic ratios of the catalysts, before and after catalytic testing, determined from XPS analysis. Values in brackets are bulk ratios determined by means of chemical analyses; the corresponding bonding energies are presented in Table S3

\begin{tabular}{llllccc}
\hline Catalyst & $\operatorname{Tr}\left({ }^{\circ} \mathrm{C}\right)$ & $\mathrm{V} /(\mathrm{V}+\mathrm{Fe})$ & $(\mathrm{Fe}+\mathrm{V}) / \mathrm{Sb}$ & $\mathrm{V}^{3+}$ & $\mathrm{V}^{4+}$ & $\mathrm{V}^{5+}$ \\
\hline $\mathrm{VSbO}_{4}$ after test & & & & & & \\
$\mathrm{V}_{0.8} \mathrm{Fe}_{0.2} \mathrm{SbO}_{4}$ before test & 900 & $1.0(1.00)$ & $1.2(0.91)$ & 31 & 46 & 24 \\
$\mathrm{~V}_{0.8} \mathrm{Fe}_{0.2} \mathrm{SbO}_{4}$ after test & 900 & $0.0(0.80)$ & $0.8(0.95)$ & - & 38 & 62 \\
$\mathrm{~V}_{0.8} \mathrm{Fe}_{0.2} \mathrm{SbO}_{4}$ after test & 700 & $0.74(0.80)$ & $1.5(0.95)$ & - & 36 & 64 \\
$\mathrm{~V}_{0.6} \mathrm{Fe}_{0.4} \mathrm{SbO}_{4}$ after test & 900 & $0.46(0.59)$ & $1.3(0.95)$ & - & 32 & 68 \\
$\mathrm{~V}_{0.35} \mathrm{Fe}_{0.65} \mathrm{SbO}_{4}$ before test & 900 & $0.40(0.34)$ & $0.7(0.95)$ & - & 31 & 69 \\
$\mathrm{~V}_{0.35} \mathrm{Fe}_{0.65} \mathrm{SbO}_{4}$ after test & 900 & $0.42(0.34)$ & $1.3(0.95)$ & - & 34 & 66 \\
$\mathrm{~V}_{0.15} \mathrm{Fe}_{0.85} \mathrm{SbO}_{4}$ after test & 900 & $0.24(0.13)$ & $0.7(0.96)$ & - & 46 & 54 \\
& & & & & &
\end{tabular}

Following testing, none of the catalysts revealed any change in the oxidation state of antimony and iron. This also confirmed the result derived from Mössbauer spectroscopy, showing that the $\mathrm{Sb}^{5+} / \mathrm{Sb}^{3+}$ redox couple is not involved in the reaction. The spectra of $\mathrm{V} 2 \mathrm{p}_{3 / 2}$ region were substantially more complex. Their spectral decomposition revealed several contributions, which were attributed to different oxidation states. The $\mathrm{V}^{4+}$ and $\mathrm{V}^{5+}$ vanadium peaks, corresponding to the $515-516 \mathrm{eV}$ and 516$517 \mathrm{eV}$ binding energies, were identified in all of the catalysts before and after catalytic testing. An 
additional contribution, corresponding to the presence of $\mathrm{V}^{3+}$ at $514.3 \mathrm{eV}$, was detected in the pure vanadium antimonate, $\mathrm{VSbO}_{4}$. The spectral decomposition of the $\mathrm{V} 2 \mathrm{p}_{3 / 2}$ signal for this catalyst is plotted in Fig. 9, revealing the presence of three oxidation states: $\mathrm{V}^{3+}, \mathrm{V}^{4+}$, and $\mathrm{V}^{5+}$.

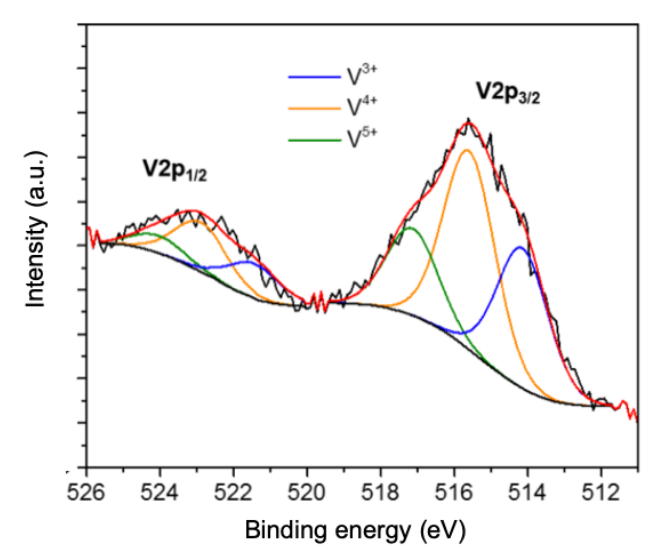

Fig. 9: Spectral decomposition of the V2p region of $\mathrm{VSbO}_{4}$ analyzed by XPS prior to testing.

Quantitative analysis of the spectra revealed an excess of antimony for the solids prior to catalytic testing, and an antimony deficiency after testing. When plotted as a function of the nominal composition (Fig. 10), this deficiency (or excess $\mathrm{V}+\mathrm{Fe}$ ) reaches a maximum (revealed by the $(\mathrm{V}+\mathrm{Fe}) / \mathrm{Sb}$ ratio), at a vanadium concentration of $80 \%$ (i.e. $20 \% \mathrm{Fe} / \mathrm{V}+\mathrm{Fe}$ ). At the same time, the ratio of the vanadium and iron contents is almost proportional to the bulk ratio, except in the case of high iron contents, where it appears to be slightly higher. A higher heat treatment temperature $\left(900^{\circ} \mathrm{C}\right.$, rather than $700^{\circ} \mathrm{C}$ ) does not appear to produce any significant change in surface composition. The $\mathrm{V}^{5+} /\left(\mathrm{V}^{4+}+\mathrm{V}^{5+}\right)$ ratio lies between $60 \%$ and $70 \%$ over the entire range of studied compounds, except for the case of the compound with the lowest vanadium content, $\mathrm{Fe}_{0.85} \mathrm{~V}_{0.15} \mathrm{SbO}_{4}$, for which equivalent proportions of $\mathrm{V}^{4+}$ and $\mathrm{V}^{5+}$ were observed. In the case of $\mathrm{VSbO}_{4}$, after catalytic testing the relative proportion of $\mathrm{V}^{3+}$ is close to that observed in the bulk material. Again, no significant change was observed in the oxidation state of vanadium, as a result of an increase in heat treatment temperature. 


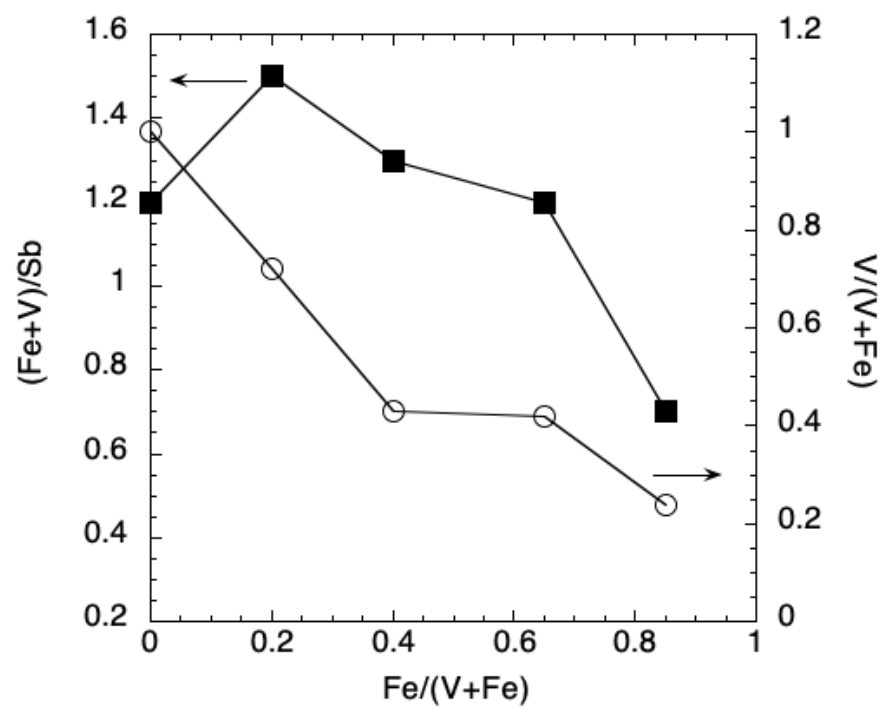

Fig. 10: Variation in surface cationic composition as a function of iron content, in the $\mathrm{V}_{1 \mathrm{x}} \mathrm{Fe}_{\mathrm{x}} \mathrm{SbO}_{4}$ solid solution.

Although there was no strong change in the degree of vanadium oxidation after testing, vanadium should have contributed to the oxidation-reduction of the catalysts. As the oxidation state of the iron and antimony remained completely unchanged, they are not expected to have contributed to the redox reaction of the catalyst. It was thus important to characterize the samples in situ, under catalytic conditions, to verify that vanadium only was responsible for the catalytic activity. In practice, it is often observed that during the recovery of a catalyst, after testing, the valence of its surface elements can easily change. Thus, in order to confidently confirm the absence of any oxidationreduction activity with the iron and antimony in the catalysts, they were subjected to in situ characterization, using XANES spectroscopy under standard catalytic conditions at $250^{\circ} \mathrm{C}$.

\subsection{Study of elemental oxidation states in operando conditions}

XANES spectroscopy is a bulk technique and therefore a sensitivity linked to this characteristic. However, it has the advantage that it can be implemented under catalytic test conditions. Two catalysts were studied using this technique: one rich in vanadium, $\mathrm{V}_{0.80} \mathrm{Fe}_{0.20} \mathrm{SbO}_{4}$, and the other rich in iron, $\mathrm{V}_{0.35} \mathrm{Fe}_{0.65} \mathrm{SbO}_{4}$. The spectra were recorded both at room temperature and at 
$250^{\circ} \mathrm{C}$, under a gas mixture close to that used for conventional catalytic testing (EtLA/ inert/ $\mathrm{O}_{2}: 12.3 /$ 66.4/ 19.3), and after a time on stream varying from $30 \mathrm{~min}$ to $2 \mathrm{~h}$. Finally, spectra were also recorded after returning to room temperature, under the same gas mixture as that used for conventional testing.

In Figs. 11, 12 and 13 we present the superimposed XANES spectra obtained with the $\mathrm{V}_{0.80} \mathrm{Fe}_{0.20} \mathrm{SbO}_{4}$ sample at each edge. The spectra at the $\mathrm{Fe} \mathrm{K}$-edge did not reveal any change in the degree of oxidation of iron, which remained in the $\mathrm{Fe}^{3+}$ oxidation state during the experiment (Fig. 11). The same conclusions were drawn for $\mathrm{Sb}$, which remained in the $\mathrm{Sb}^{5+}$ oxidation state (Fig. 12).

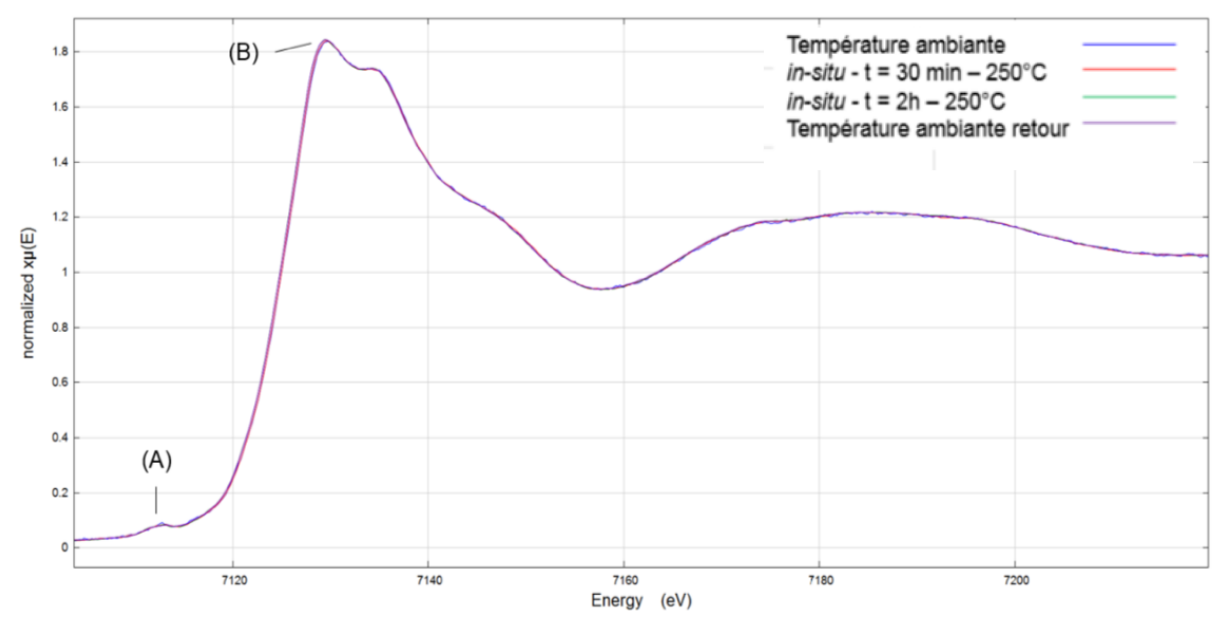

Fig. 11: Superimposed XANES spectra recorded for the $\mathrm{Fe}_{0.2} \mathrm{~V}_{0.8} \mathrm{SbO}_{4}$ compound at the $\mathrm{Fe} \mathrm{K}$-edge, at room temperature and at $250^{\circ} \mathrm{C}$, under catalytic reaction conditions and after different reaction times.

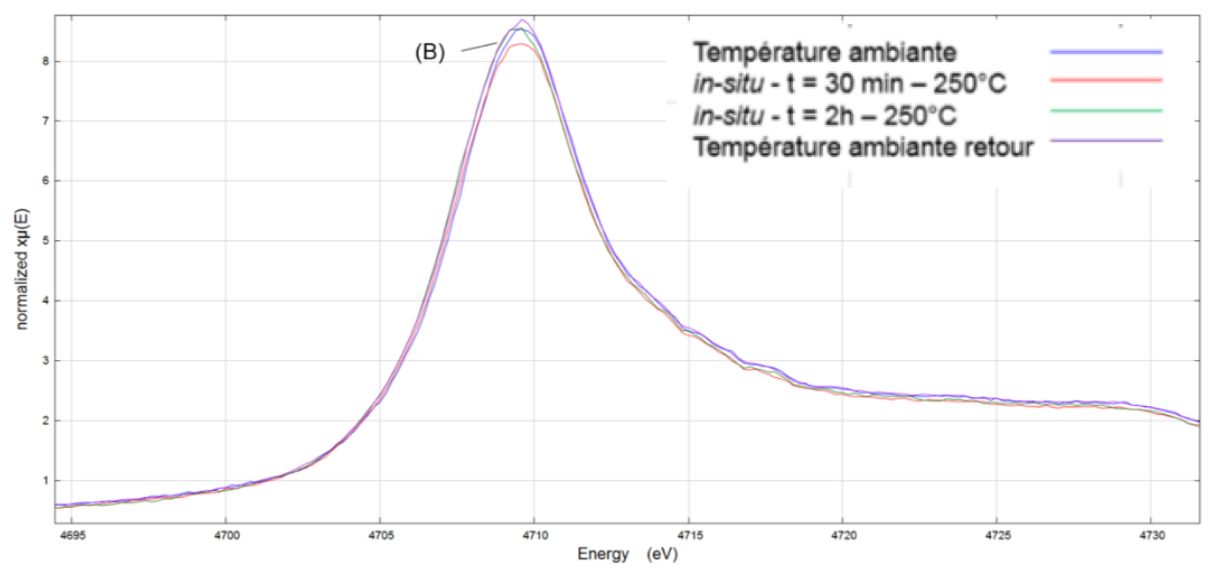


Fig. 12: Superimposed XANES spectra recorded for the $\mathrm{Fe}_{0.2} \mathrm{~V}_{0.8} \mathrm{SbO}_{4}$ compound at the $\mathrm{Sb} \mathrm{L}_{1}$-edge, at room temperature and at $250^{\circ} \mathrm{C}$, under catalytic reaction conditions and after different reaction times.

These results show that neither iron nor antimony took part in the oxidation-reduction of the catalyst. On the contrary, as shown by the enlarged portion of the spectra in the energy range corresponding to the pre-peak of vanadium, there is a gradual shift from the center of mass of this pre-peak towards lower energies, under catalytic test conditions (Fig. 11). This shift is produced by a slight reduction of vanadium. It is interesting to note that after returning to room temperature, the vanadium was still reduced, as was the case at $250^{\circ} \mathrm{C}$ under reaction conditions, whereas in the case of a standard test, XPS characterization after testing appeared to show that the vanadium was re-oxidized, since its oxidation state was comparable with that observed prior to testing. This might be explained by the fact that, due to the lower mass and thermal inertia of the catalyst in a in situ cell, the catalyst is quenched at ambient temperature, whereas in the case of conventional testing, it has time to re-oxidize during slow cooling.

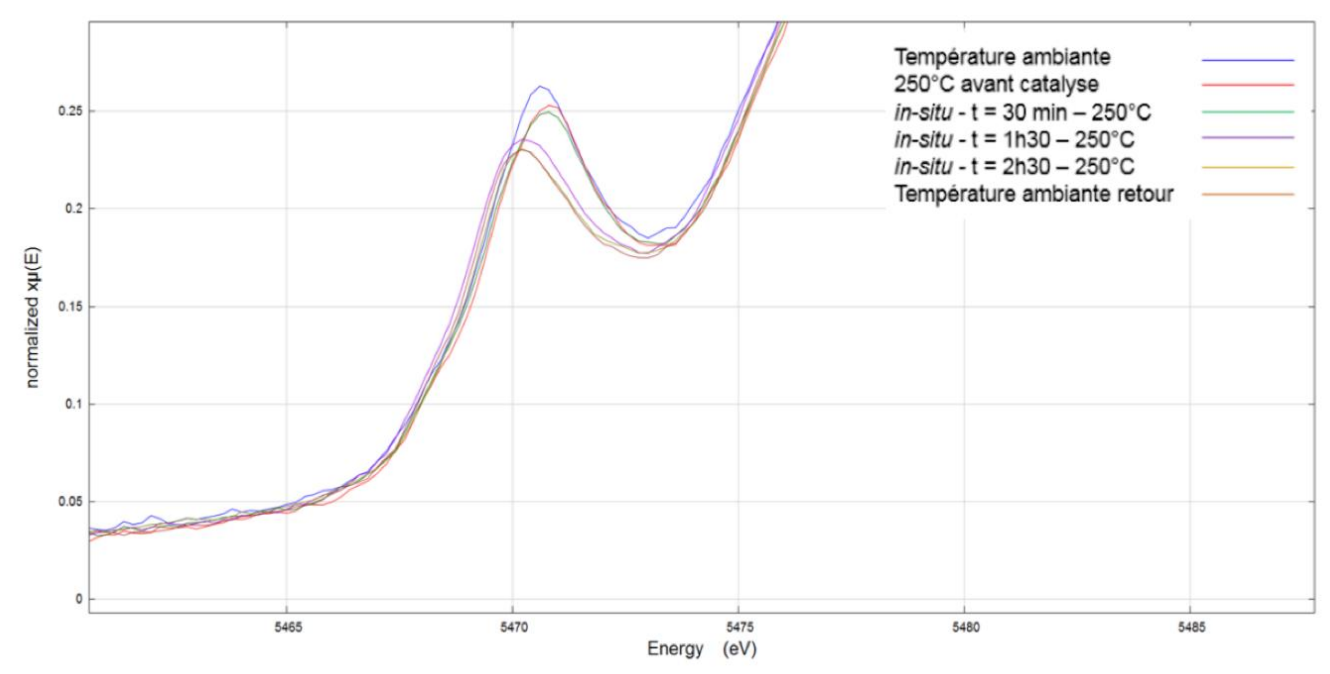

Fig. 13: Superposition of the XANES spectra of the $\mathrm{Fe}_{0.2} \mathrm{~V}_{0.8} \mathrm{SbO}_{4}$ compound at $\mathrm{V}$ K-edge recorded at room temperature and at $250^{\circ} \mathrm{C}$ in catalytic reaction conditions and after different times of the reaction.

As in the case of the vanadium-rich compound, the XANES spectra of the $\mathrm{Fe}_{0.65} \mathrm{~V}_{0.35} \mathrm{SbO}_{4}$ sample showed that, contrary to the case of vanadium, iron and antimony were never reduced (Fig. S4). 


\section{Discussion}

The results of this study are in line with many previous experimental observations, and in agreement with most of the models proposed for the active phase of vanadium antimonate in other oxidation reactions [19]. When compared to other catalysts, mixed iron and vanadium antimonates are very active and selective for the oxidative dehydrogenation of ethyl lactate into ethyl pyruvate [3-8]. Our analysis of the catalytic properties, together with the physico-chemical characteristics of this family of catalysts, shows that the cationic composition and temperature of preparation are key parameters in terms of their efficiency. Their catalytic activity reaches a maximum when the vanadium content is close to $80 \%$, for all temperatures of synthesis. This optimal bulk composition has already been observed with these catalysts, in other oxidation reactions such as the oxidation of propane to acrylic acid.

XPS characterization of the catalysts showed that in the case of $\sim 80 \%$ vanadium content in the bulk composition, the surface vanadium composition is maximized. This confirms that vanadium is the active element involved in these catalysts. Furthermore, in the case of catalyst solids annealed at $900^{\circ} \mathrm{C}$, when the intrinsic rate of ethyl lactate conversion at $250^{\circ} \mathrm{C}$ is plotted as a function of the catalyst's surface $\mathrm{V}^{5+}$ content, a practically linear relationship is observed (Fig. 14). 


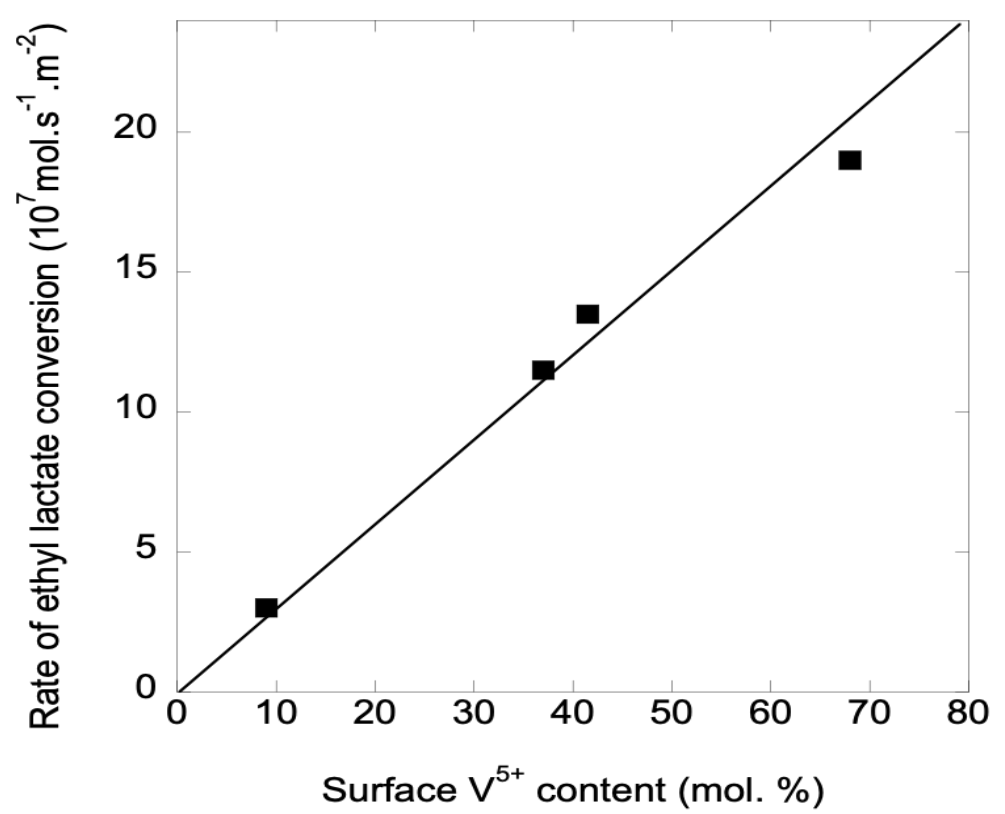

Fig. 14 : Rate of ethyl lactate conversion measured at $250^{\circ} \mathrm{C}$ on catalysts prepared at $900^{\circ} \mathrm{C}$ (Fig. 6) as a function of their surface $\mathrm{V}^{5+}$ content calculated from data in Table 6.

The surface $(\mathrm{V}+\mathrm{Fe}) / \mathrm{Sb}$ ratio of the catalysts is greater than unity, suggesting that subsurface vanadium species are present at the surface. These $\mathrm{V}^{5+}$ species, which appear to be formed under stream (since the $(\mathrm{V}+\mathrm{Fe}) / \mathrm{Sb}$ ratio increases between before and after testing), are likely to be the catalytic active species. Interestingly, electron spin resonance analysis has shown that the highest concentration of bulk isolated $\mathrm{V}^{4+}$ species is encountered with $\mathrm{V}_{0.8} \mathrm{Fe}_{0.2} \mathrm{SbO}_{4}$ [15]. Thus, it is possible that the $\mathrm{V}^{4+}$ surface species are oxidized, and are also active. In the case of the Mars and van Krevelen redox mechanism, bulk and surface characterizations have shown that neither $\mathrm{Fe}$ nor $\mathrm{Sb}$ are involved in this mechanism. This can be understood by considering the redox potentials of the different cationic couples. These can be classified in terms of their binding energies, in the following order: $\mathrm{Fe}^{3+} / \mathrm{Fe}^{2+}>\mathrm{Sb}^{5+} / \mathrm{Sb}^{3+}>\mathrm{V}^{5+} / \mathrm{V}^{4+}>\mathrm{V}^{4+} / \mathrm{V}^{3+}$, with the $\mathrm{Fe}^{3+} / \mathrm{Fe}^{2+}$ and $\mathrm{Sb}^{5+} / \mathrm{Sb}^{3+}$ redox couples being relatively close ( 0.77 and $0.75 \mathrm{eV}$ respectively). In the solid state, for example in $\mathrm{FeVO}_{4}$ and $\left(\mathrm{Fe}_{1-}\right.$ $\left.{ }_{x} \mathrm{~V}_{\mathrm{x}}\right)_{18} \mathrm{O}_{36}$, the $\mathrm{Fe}^{3+}$ is systematically in equilibrium with $\mathrm{V}^{5+}, \mathrm{V}^{4+}$ and even $\mathrm{V}^{3+}$ [33]. For antimony, the $\mathrm{Sb}^{5+}$ state is found to be in equilibrium with $\mathrm{Fe}^{3+}$, as is the case with $\mathrm{FeSbO}_{4}$ [14]. Although the $\mathrm{FeSb}_{2} \mathrm{O}_{6}$ phase exists, it is unstable and converts to $\mathrm{FeSbO}_{4}$ and $\mathrm{Sb}_{2} \mathrm{O}_{4}\left(\mathrm{Fe}^{2+}+\mathrm{Sb}^{5+} \rightarrow \mathrm{Fe}^{3+}+\mathrm{Sb}^{3+}\right)$ 
[34]. It thus follows that in $\mathrm{Fe}_{\mathrm{x}} \mathrm{V}_{1-\mathrm{x}} \mathrm{SbO}_{4}$ compounds, the iron and antimony redox couples are not involved in the re-oxidation of vanadium. This does not mean that they play no role in the catalytic properties of these compounds. Indeed, they isolate and host the active vanadium cations, without creating strong acid sites that could interfere with the catalyst's selectivity, by favoring the decomposition of the esters and their further transformation. An earlier study on this subject has shown that a solid solution of $\mathrm{V}_{1-\mathrm{x}} \mathrm{Fe}_{\mathrm{x}} \mathrm{SbO}_{4}$ has few Brønsted acid sites, in particular in the case of vanadium-rich compounds [19]. Such Brønsted sites could also correspond to adsorption sites for ethyl lactate.

The heat treatment temperature applied to the catalysts has been shown to influence their catalytic activity and selectivity. Although higher heat treatment temperatures tend to decrease their specific surface area, this effect alone cannot explain their lower activity, as shown in Fig. 5. It is possible that improved crystallinity, such as that obtained at higher temperatures, favors the activity and selectivity of these solids. In the specific case of $\mathrm{V}_{0.8} \mathrm{Fe}_{0.2} \mathrm{SbO}_{4}$ treated at $700^{\circ} \mathrm{C}$, this catalyst had the highest $(\mathrm{V}+\mathrm{Fe}) / \mathrm{Sb}$ surface ratio after testing, but also the lowest selectivity to ethyl pyruvate. It is possible that beyond a certain level of vanadium surface enrichment, oxide clusters are formed. These could be responsible for the observed decrease in selectivity to ethyl pyruvate, in favor of overoxidation products.

The predominant characteristic of a catalytic phase capable of operating with an Mvk mechanism is often its ability to adopt a surface more reduced or oxidized than the bulk without change in the structure. This change in surface state, which is reversible and may be initiated by the pretreatment temperature or the catalytic reaction, can be achieved either by redox of the elements and the formation of oxygen vacancies or by diffusion of elements from the bulk to the surface. This diffusion can however lead to the extraction of a given species which can become the active species as in this case study, or participate in a different way to the reaction mechanism [35,36]. This happens for example on similar catalysts used for the ammoxidation of propane, when antimony in the form of amorphous oxide dispersed over the rutile structure is present. These subsurface species then become a fundamental component of the catalyst. 
Finally, in addition to their proven effectiveness in the oxidative dehydrogenation of ethyl lactate, these catalysts are considerably more stable than the best catalysts known hitherto, which are polyoxometallates [8]. When prepared at $900^{\circ} \mathrm{C}$, these new catalysts are more thermally stable and their catalytic properties do not vary when they are maintained under catalytic conditions for long periods of time. Moreover, during the present study it was found that when these catalysts were momentarily submitted to a catalytic atmosphere, from which the oxygen or ethyl lactate had been removed, they quickly recovered their activity and selectivity when the complete atmosphere was reformed. This is not the case for polyoxometallate-based catalysts, which are irreversibly transformed under these conditions, and lose their catalytic properties.

\section{Conclusion}

This research has shown that by optimizing the composition and method of preparation of iron and vanadium antimonates, it is possible to obtain catalysts with a better performance than that of molybdenum polyoxometallates, which were until now the best-known catalysts for the gas phase conversion of ethyl lactate.

The best iron and vanadium antimonate catalysts were found to be those prepared at $900^{\circ} \mathrm{C}$, which allowed an ethyl lactate conversion of $87 \%$, and an ethyl pyruvate selectivity of $88 \%$ to be achieved at $275^{\circ} \mathrm{C}$. In addition, these catalysts are very stable under reaction conditions, and could be straightforwardly applied to industrial processes in the future.

The working mechanism of these catalysts is highly comparable to that demonstrated for other reactions for which they are also active and selective, as in the case of the oxidative dehydrogenation of ethanol to acetaldehyde. Their characterization before and after catalytic testing, as well as in situ, showed that the $\mathrm{Sb}^{3+} / \mathrm{Sb}^{5+}$ and $\mathrm{Fe}^{2+} / \mathrm{Fe}^{3+}$ redox couples are not involved in any step of the catalytic reaction, and that the active sites are the surface $\mathrm{V}^{5+}$ species.

The latter are believed to correspond to sub-surface species, which are apparently formed during catalytic testing. Their relative surface content and consequently the activity of the catalysts varies 
with the bulk composition, reaches a maximum for a bulk composition close to $\mathrm{V}_{0.8} \mathrm{Fe}_{0.2} \mathrm{SbO}_{4}$. It is likely that the presence of numerous cationic vacancies in the richer vanadium mixed oxide slows down the surface diffusion of vanadium. It is also possible that a certain proportion of the most active species remain in the form of isolated surface species. It has previously been shown that the highest number of such species in the bulk is observed when the composition is close to $\mathrm{V}_{0.8} \mathrm{Fe}_{0.2} \mathrm{SbO}_{4}$. Finally, although $\mathrm{Fe}$ and $\mathrm{Sb}$ are not directly involved in the catalytic reaction, they allow a rutile structure to be formed, which optimally hosts the vanadium, without producing the strong surface acid sites that have been shown to be detrimental to the selectivity of ethyl pyruvate.

To conclude, the high efficiency and robustness of the catalysts developed in the context of this study could allow them to be included in the development of a new process for the production of 2-Keto-4-Methylthio Butyric acid. Such a process would be sustainable, and should be economically viable if suitable catalysts are developed for the other steps. All of the reaction steps could be implemented as part of a continuous gas phase process.

\section{Acknowledgments}

The authors would like to gratefully acknowledge ADISSEO company for financial support. XANES spectroscopy characterization made at Soleil Synchrotron was supported by a public grant overseen by the French National Research Agency (ANR) as part of the "Investissements d'Avenir" program (reference: ANR10-EQPX45).

\section{References}


[1] P. Rey, G. Blanchard, US20080069920, 2008, attributed to Adisseo

[2] C. S. M. Pereira, V. M. T. M. Silva, A. E. Rodrigues, Green Chem., 13 (2011) 2658-2664.

[3] F. Thalhammer, K.-H. Schrank, K. Wernthaler, Sueddeutsche Kalkstickstoff, DE19756584, 1999.

[4] H. Hayashi, S. Sugiyama, N. Masaoka, N. Shigemoto, Catal. Lett. 19 (1993) 273-277.

[5] M. Qian, M.A. Liauw, G. Emig, Appl. Catal. A : Gen. 238 (2003) 211-222.

[6] J. Shen, W. Ji, Y. Han, Y. Chen, CN1359893, 2002, attributed to Nanjing university

[7] T.T.N. Nguyen, M. Huchede, E. Blanco, F. Morfin, J.L. Rousset, L. Massin, M. Aouine, V. Bellière-Baca, J.M.M. Millet, Appl. Catal. A: Gen. 549 (2018) 170-178.

[8] M. Huchede, D. Morvan, V. Bellière-Baca, J.M.M. Millet, A: Gen. 601 (2020) 117619.

[9] J. R. Ebner, Monsanto Company, US4405498, 1983

[10] A.T. Guttman, R.K. Grasselli, J.F. Brazdil Jr., Standard Oil Company, US4746641, 1985

[11] A. T. Guttman, R. K. Grasselli, J. F. Brazdil Jr., Standard Oil Company, US4788317,

[12] S. Albonetti, G. Blanchard, P. Burattin, F. Cavani, S. Masetti, F. Trifiro, Catal. Today 42 (1998) 283-295.

[13] R.K. Grasseli, S.T. Oyama, A.M. Gaffney, J.E. Lyons, Stud. Surf. Sci. and Catal. 110 (1997) 413422

[14] H. Roussel, B. Mehlomakulu, F. Belhadj, J.M.M. Millet, J. Catal. 205(1) (2002) 97-106.

[15] D. L. Nguyen, Y. B. Taarit, J. M. M. Millet, Catal. Lett. 90 (2003) 65-70.

[16] J. Bilde, P. Delichere, L. Burel, S. Loridant, J.M.M. Millet, Appl. Catal. A : Gen. 468 (2013) 341349.

[17] J. Nilsson, A. R. Landa-Canovas, S. Hansen, A. Andersson, J. Catal. 160 (1996) 244- 253

[18] J. Nilsson, A.R. Landa-Canovas, S. Hansen, A. Andersson, J. Catal. 186 (1999) 442- 457

[19] B. Mehlomakulu, T.T.N. Nguyen, P. Delichère, E. van Steen, J.M.M. Millet, J. Catal. 289 (2012) $1-10$.

[20] M. Allen, R. Betteley, M. Bowker, G.J. Hutchings, Catal. Today, 9 (1991) 97-104

[21] R. Nilsson, T. Linblad, A. Andersson, C. Song, S. Hansen, Stud. Surf. Sci. Catal., 82 (1994) 281292.

[22] J.M.M. Millet, C. Virely, M. Forissier, P. Bussière, J.C. Vedrine, Hyperfine Interact. 46 (1989) 619-628.

[23] F. J. Berry, F. J. G. Holden, M. H. Loretto, J. Chem Soc., Dalton Trans. 7 (1987) 1727-1732. 
[24] A. Andersson, S.L.T. Andersson, G. Centi, R.K. Grasselli, M. Sanati, F. Trifiro, Appl. Catal. A. 113 (1994) 43-57.

[25] D.S. Bachu, R.G. Egdell, G. Sankar, C.J. Carmalt, I.P. Parkin, J. Mater. Chem. C 5 (2017) 96949701.

[26] T. Birchall, J.A. Connor, I.H. Hillier, J. Chem. Soc. Dalton. Trans. (1974) 558-565.

[27] R. Izquierdo, E. Sacher, A. Yelon, Appl. Surf. Sci. 40 (1989) 175-177.

[28] R. Delobel, H. Baussart, J. Leroy, J. Grimblot, L. Gengembre, J. Chem. Soc. Faraday Trans. I 79 (1983) 879-891.

[29] T. Yamashita, P. Hayes, Appl. Surf. Sci. 254 (2008) 2441-2449.

[30] G.-J. Dong, Y. Bai, Y.-F. Zhang, Y. Zhao, New J. Chem. 39 (2015) 3588-3596.

[31] C. La Fontaine, L. Barthe, A. Rochet, V. Briois, Catal. Today 205 (2015) 148-158.

[32] O.V. Safonova, B. Deniau, J.M.M. Millet, J. Phys. Chem. B 110 (2010) 23962-23967.

[33] J. Muller, J.C. Joubert, M. Marezio, J. Solid State Chem. 18 (1976) 351-362.

[34] A. Yu. Nikulin, E. A. Zvereva, V. B. Nalbandyan, I. L. Shukaev, A. I. Kurbakov, M. D.

Kuchugura, G. V. Raganyan, Yu. V. Popov, V. D. Ivanchenko, A. N. Vasiliev, Dalton Trans. 46 (2017) 6059-6068.

[35] A. Chieregato, J. M. Lopez Nieto, F. Cavani, Coord. Chem. Rev. 301-302 (2015) 3-23.

[36] K. Routray, W. Zhou, C.J. Kiely and I.E. Wachs, ACS Catal. 1 (2011) 54-66.

\section{FIGURE CAPTION}

Fig. 1 : Addition reaction of methyl mercaptan with keto vinylic acid for KMB production.

Fig. 2 : Oxidative dehydrogenation and aldolization reaction for the production of KVA.

Fig. 3: X-ray diffraction patterns of the $\mathrm{V}_{0.35} \mathrm{Fe}_{0.65} \mathrm{SbO}_{4}$ mixed iron and vanadium antimonate catalyst, treated at different temperatures: a) $350^{\circ} \mathrm{C}$ b) $700^{\circ} \mathrm{C}$ and c) $900^{\circ} \mathrm{C}$.

Fig. 4: X-ray diffraction patterns of mixed iron and vanadium antimonates: a) $\mathrm{VSbO}_{4}$, b) $\mathrm{V}_{0.8} \mathrm{Fe}_{0.2} \mathrm{SbO}_{4}, \mathrm{c}$ ) $\mathrm{V}_{0.4} \mathrm{Fe}_{0.60} \mathrm{SbO}_{4}$, d) $\mathrm{V}_{0.35} \mathrm{Fe}_{0.65} \mathrm{SbO}_{4}$, e) $\mathrm{VxFexSbO}_{4}$.

Fig. 5: SEM images of two catalysts: $\mathrm{V}_{0.8} \mathrm{Fe}_{0.2} \mathrm{SbO}_{4}$ (a and b) and $\mathrm{V}_{0.35} \mathrm{Fe}_{0.65} \mathrm{SbO}_{4}$ (c and d).

Fig. 6 : Rate of ethyl lactate conversion and selectivity to ethyl pyruvate as a function of the iron content in the $\mathrm{V}_{1-\mathrm{x}} \mathrm{Fe}_{x} \mathrm{SbO}_{4}$ catalysts at $250^{\circ} \mathrm{C}$, under standard conditions. 
Fig. 7 : Variations in (a) rate of ethyl lactate conversion and selectivity to ethyl pyruvate, and (b) selectivity to by-products, as a function of the $\mathrm{O}_{2}$ to ethyl lactate molar ratio at $250^{\circ} \mathrm{C}$, under standard conditions.

Fig. 8: ${ }^{57} \mathrm{Fe}$ Mössbauer absorption spectra of the $\mathrm{V}_{0.8} \mathrm{Fe}_{0.2} \mathrm{SbO}_{4}$, and $\mathrm{V}_{0.4} \mathrm{Fe}_{0.60} \mathrm{SbO}_{4}$ samples before and after catalytic testing. The solid lines are phenomenological fits.

Fig. 9: Spectral decomposition of the $\mathrm{V} 2 \mathrm{p}$ region of $\mathrm{VSbO}_{4}$ analyzed by $\mathrm{XPS}$ prior to testing.

Fig. 10: Variation in surface cationic composition as a function of iron content, in the $\mathrm{V}_{1 \mathrm{x}} \mathrm{Fe}_{\mathrm{x}} \mathrm{SbO}_{4}$ solid solution.

Fig. 11: Superimposed XANES spectra recorded for the $\mathrm{Fe}_{0.2} \mathrm{~V}_{0.8} \mathrm{SbO}_{4}$ compound at the $\mathrm{Fe} \mathrm{K}$-edge, at room temperature and at $250^{\circ} \mathrm{C}$, under catalytic reaction conditions and after different reaction times.

Fig. 12: Superimposed XANES spectra recorded for the $\mathrm{Fe}_{0.2} \mathrm{~V}_{0.8} \mathrm{SbO}_{4}$ compound at the $\mathrm{Sb} \mathrm{L}_{1}$-edge, at room temperature and at $250{ }^{\circ} \mathrm{C}$, under catalytic reaction conditions and after different reaction times.

Fig. 13: Superposition of the XANES spectra of the $\mathrm{Fe}_{0.2} \mathrm{~V}_{0.8} \mathrm{SbO}_{4}$ compound at $\mathrm{V}$ K-edge recorded at room temperature and at $250^{\circ} \mathrm{C}$ in catalytic reaction conditions and after different times of the reaction.

Fig. 14: Rate of ethyl lactate conversion as a function of the surface $\mathrm{V}^{5+}$ content.

Fig. S1: Evolution of the cross sections of Sb3d and Sb4d as a function of the energy incident X-rays. As a reminder, the source used emitted photons of energy corresponding to the $\mathrm{K} \alpha$ of aluminum, at $1486.6 \mathrm{eV}$.

Fig. S2: XPS spectrum of the Sb3d core level region of antimony oxide showing the superposition of O1s and Sb3d5/2 signals.

Fig. S3 : Logarithm of the rate of transformation of ethyl lactate as a function of the logarithm of the oxygen partial pressure at $250^{\circ} \mathrm{C}$ at a constant ethyl lactate partial pressure of $12.5 \mathrm{kPa}$.

Fig. S4 : Full survey spectrum of the $\mathrm{V}_{0.35} \mathrm{Fe}_{0.65} \mathrm{SbO}_{4}$ sample recorded after catalytic testing at $250^{\circ} \mathrm{C}$.

Fig. S5 : XANES spectra of the of the $\mathrm{V}_{0.35} \mathrm{Fe}_{0.65} \mathrm{SbO}_{4}$ sample recorded at room temperature and at $250^{\circ} \mathrm{C}$ in catalytic reaction conditions and after different times of the reaction a) at Fe K-edge, b) at $\mathrm{Sb} \mathrm{L}_{1}$-edge and c) at $\mathrm{V}$ K-edge. 